\title{
On-line Preconcentration System for Lead(II) Determination in Waste Water by Atomic Absorption Spectrometry Using Active Carbon Loaded with Pyrogallol Red
}

\author{
Ali A. Ensafi, ${ }^{\dagger}$ Taghi Khayamian, and Mohammad H. Karbasi \\ College of Chemistry, Isfahan University of Technology, Isfahan-84156, Iran
}

\begin{abstract}
An on-line system for enrichment and determination of lead(II) is presented. It is based on the adsorption of lead(II) ions on a minicolumn packed with active carbon loaded with Pyrogallol Red. After preconcentration step, the metal ions are eluted automatically by $5.0 \mathrm{ml}$ of $0.50 \mathrm{M}$ nitric acid solution and the lead ion contents were determined by atomic absorption spectrometry. The influence of chemicals, $\mathrm{pH}$ and flow variables were studied as well as effect of potential interfering ions. Under the optimum conditions, the lead ions in aqueous samples were concentrated about 100 fold by the column. The detection limit was $0.001 \mu \mathrm{g} \mathrm{ml}^{-1}$. The recovery percent of spliced lead(II) was in the range of $98 \%-$ $103 \%$.
\end{abstract}

(Received August 9, 2002; Accepted March 26, 2003)

\section{Introduction}

The determination of trace amounts of lead in environmental samples is currently of great importance due to their high toxicity, accumulative and persistent character in the environment and living organisms. Thus, there is great interest concerning the implementation of a reliable preconcentration system for lead(II) for analytical determinations. At the moment, one of the most used matrix removal preconcentration methods is the on-line retention of the analyte on an adequate solid support by using microcolumns in a flow system, based on mass transfer between a liquid phase and a solid one. ${ }^{1}$ These preconcentration systems can be on-line coupled to several atomic detection techniques. Flame atomic absorption spectrometry (FAAS) is a simple and very available technique for the determination of heavy metals in water samples. However, the main problem is a low sensitivity for trace metal at the $\mathrm{ng} / \mathrm{ml}$ level. This limitation can be overcome by using a preconcentration procedure. Solid-phase extraction (SPE) techniques have found increasing applications for the preconcentration of trace metal ions and the elimination of matrix interference prior to an AAS analysis. Activated carbon is one of the sorbent materials that have been used as collectors for trace elements. ${ }^{2-4}$ Solid-phase extraction procedures based on the sorption of metal complexes on activated carbon have been widely applied. ${ }^{2-6}$ In most of the previous studies, metal complexes were collected on activated carbon as a filter. Then, the preconcentrated trace metals on the filter were recovered by treating with suitable solvents, such as nitric acid. Thus, the prepared activated carbon filter was used only for one analysis. Several complexing agents have been used in the adsorption process on activated carbon, including dithiozone, dithiocarbamate derivatives, ${ }^{8,9}$ 1-(2-pyridylazo)2-naphthol, ${ }^{10,11}$ resorcinol derivatives, ${ }^{12} \quad$ 1-nitrous-2-naphtol, ${ }^{13} \quad o, o$-diethyl-

To whom correspondence should be addressed. dithiophosphate ${ }^{14,15}$ and pyrocatechol violet. ${ }^{16}$ In all of these methods, a ligand solution was needed for each experiment, because, the chelating agent was used to wash metal ions from the surface of sorbent.

In this paper, a new on-line column separationpreconcentration method is described for the determination of $\mathrm{Pb}$ (II) by using active carbon loaded with Pyrogallol Red (PGR) and FAAS. Active carbon tightly adsorbed Pyrogallol Red and thus the adsorbed Pyrogallol Red did not wash away with the washing solution that was used to remove lead(II) ions from the column. Automation of the procedure can possibly reduce the risk of operational errors, increase the precision of the method and accelerate the sample throughput. ${ }^{17}$

\section{Experimental}

\section{Reagents and chemicals}

All solutions were prepared with doubly distilled water, unless otherwise stated. A Pyrogallol Red (PGR) solution was prepared by dissolving a suitable amount of PGR (Merck) in a water/ethanol $(50: 50 \mathrm{v} / \mathrm{v})$ mixture. A buffer solution $(0.1 \mathrm{M})$ was prepared by adding an appropriate amount of $\mathrm{NaOH}$ to a potassium hydrogen phthalate solution for $\mathrm{pH} 3-6$ and a borate buffer solution $(0.1 \mathrm{M}, \mathrm{pH} 7-10)$ was prepared by adding an appropriate amount of sodium hydroxide solution $(0.1 \mathrm{M})$ to boric acid solution.

Activated carbon powder, used as a base of adsorbent in the preconcentration of lead(II) ions (Merck, No. 2180), was treated with concentrated $\mathrm{HCl}$, washed with distillated water and dried at $110^{\circ} \mathrm{C}$

\section{Apparatus}

A Perkin-Elmer Model 2380 flame atomic absorption spectrometer was used. Atomic absorption measurements were carried out using air-acetylene flame. A hollow lead cathode lamp (Perkin-Elmer) operated at $10 \mathrm{~mA}$ was used as radiation 


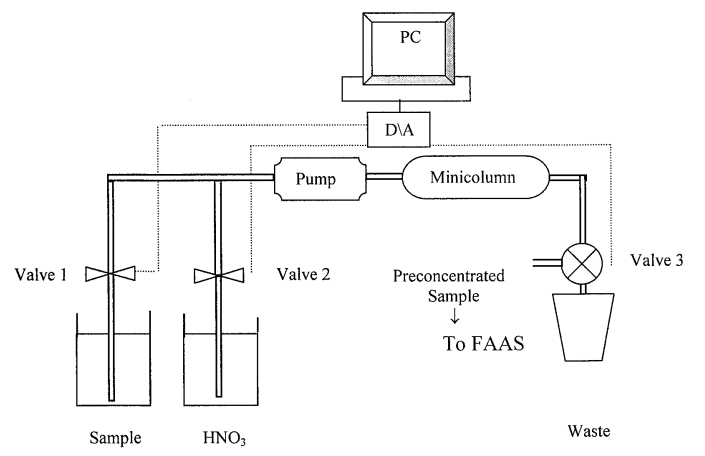

Fig. 1 Automatic manifold system used for the preconcentration of $\mathrm{Pb}$ (II).

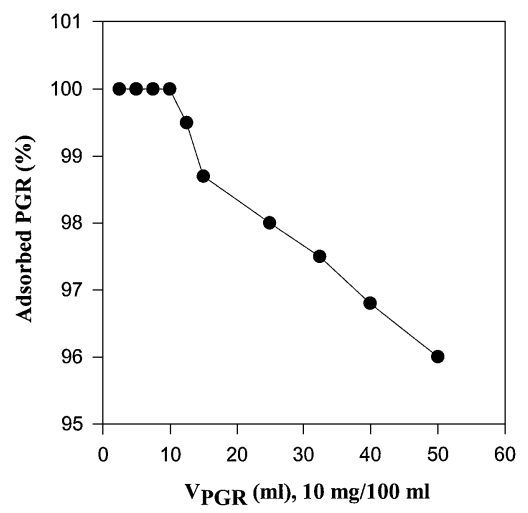

Fig. 2 Capacity of activated carbon for the adsorption of PGR.

power. The wavelength was set to $217.0 \mathrm{~nm}$ and the slit width to $0.7 \mathrm{~nm}$. All other operating parameters for the working element were set of as recommended by the manufacture.

A schematic diagram of the on-line preconcentration is shown in Fig. 1. The hardware of the system was composed of a 32channel I/O card (PCL-720, Advantech, Taiwan) which was a power relay module to convert the output of I/O card to $220 \mathrm{~V}$ AC, a peristaltic pump (Ismatiec ISM 404), three $220 \mathrm{~V}$ AC electrical valves, silicon rubber pump tubing (1.5 $\mathrm{mm}$ i.d.) and a $\mathrm{PC}$, Pentium II $(233 \mathrm{MHz})$. A program was written in $\mathrm{C}^{++}$by the authors to monitor and control the system.

A spectrophotometer (Genesys, Model 20) was used to measure the absorbance of the solution of PGR for checking the PGR concentration with a $1.0 \mathrm{~cm}$ glass cell at the corresponding $\lambda_{\max }$ for different $\mathrm{pH}$ values.

\section{Preparation of modified activated carbon}

In a $1000-\mathrm{ml}$ beaker, $5.0 \mathrm{~g}$ activated carbon was added to 800 $\mathrm{ml}$ of Pyrogallol Red $(10 \mathrm{mg} / 100 \mathrm{ml})$ and mixed well. After 24 $\mathrm{h}$, the mixture was filtrated and washed with water three times, each time with $10 \mathrm{ml}$ water, and then dried out. Then, a Teflon column $(1.0 \mathrm{~cm}$ length and $0.5 \mathrm{~cm}$ in diameter) packed with $0.20 \mathrm{~g}$ of modified activated carbon was used. The bed height in the column was $1 \mathrm{~cm}$.

\section{Procedure}

The method was tested with model solutions before its application to real samples. A $250 \mathrm{ml}$ portion of a $0.020 \mu \mathrm{g} / \mathrm{ml}$ $\mathrm{Pb}$ (II) solution, buffered at $\mathrm{pH}=5.5$, was passed through the column, by opening electrical valves 1 and 3 (Fig. 1) at a rate of $3.0 \mathrm{ml} / \mathrm{min}$. After finishing the solution, valve 1 was
Table 1 Influence of the $\mathrm{pH}$ on the adsorption of PGR on active carbon

\begin{tabular}{rccc}
\hline $\mathrm{pH}$ & $\lambda_{\max }$ & Absorbance $^{\mathrm{a}}$ & Absorbance $^{\mathrm{b}}$ \\
\hline 2.0 & 480 & 0.163 & 0.014 \\
3.2 & 480 & 0.155 & 0.011 \\
4.1 & 500 & 0.155 & 0.070 \\
5.2 & 515 & 0.160 & 0.055 \\
6.0 & 535 & 0.312 & 0.000 \\
7.0 & 540 & 0.385 & 0.019 \\
8.4 & 540 & 0.387 & 0.021 \\
9.0 & 540 & 0.348 & 0.088 \\
10.0 & 540 & 0.264 & 0.037 \\
\hline
\end{tabular}

a. Before treatment with active carbon.

b. After treatment with active carbon.

automatically closed and valves 2 and 3 were opened. Therefore, $5.0 \mathrm{ml}$ of $0.5 \mathrm{M}$ nitric acid was passed through the column to elute the $\mathrm{Pb}$ (II) ions. The eluent was collected and analyzed for $\mathrm{Pb}$ (II) by flame atomic absorption spectrometry. The percent of metal ions adsorbed on the column for a known concentration of $\mathrm{Pb}$ (II) was calculated from the amount of $\mathrm{Pb}$ (II) ions in the starting sample and the amount of $\mathrm{Pb}$ (II) eluted from the column.

\section{Results and Discussion}

Pyrogallol Red is a ligand that is widely used ${ }^{18-21}$ for analytical determination. It has a large formation constant with $\mathrm{Pb}$ (II). In addition, this ligand acts as a selective complexing agent for $\mathrm{Pb}$ (II) at $\mathrm{pH}=5-6.5$. On the other hand, we found that this ligand can be adsorbed onto activated carbon, due to the similarity of its structure with the structure of active carbon. After the adsorption of PGR onto the surface of active carbon, it is completely stable and does not wash off when using an $\mathrm{HNO}_{3}$ solution as a washing solvent for lead(II). This means that the activated carbon treated with PGR solution can be used several times for the preconcentration of lead(II) without decreasing the enrichment factor of the solid phase. This may be due to the similarity of the PGR structure with activated carbon, producing a strong $\pi$ - $\pi$ interaction.

First, to find the optimum $\mathrm{pH}$ for the adsorption of PGR on the active carbon surface, buffer solutions were used. For this purpose, $5.0 \mathrm{ml}$ of a $10 \mathrm{mg} / 100 \mathrm{ml}$ PGR solution and $10 \mathrm{ml}$ of a buffer solution $(\mathrm{pH}=2.0-10.0)$ plus $0.10 \mathrm{~g}$ activated carbon were mixed in a $25-\mathrm{ml}$ beaker. After $12 \mathrm{~h}$, the mixture was filtered, and washed with water, and the filtrate was diluted to $100 \mathrm{ml}$ with water. Then, the absorbance of the filtrated solution was measured spectrophotometrically to find any unadsorbed PGR, according to the calibration curve. The results show that (Table 1 ) the best $\mathrm{pH}$ for the adsorption of PGR on activated carbon is 6.0 (phthalate, $0.01 \mathrm{M}$ ).

The capacity of activated carbon for PGR was checked. For this proposes, into a series of 25-ml beakers, $10 \mathrm{ml}$ of a buffer solution (pH 6.0) plus 5.0 to $50.0 \mathrm{ml}$ of a $10 \mathrm{mg} / 100 \mathrm{ml}$ PGR solution were added, and the solution was mixed with $0.10 \mathrm{~g}$ of activated carbon. After $12 \mathrm{~h}$, the mixture was filtered and the solid was washed three times with $10 \mathrm{ml}$ of water. Then, the filtered solution was diluted to $100 \mathrm{ml}$ with water and the absorbance of the filtered solution was measured spectrophotometrically to find the free Pyrogallol Red (unadsorbed). The results are shown in Fig. 2. From the results, one gram of active carbon can completely adsorb $10 \mathrm{mg}$ 


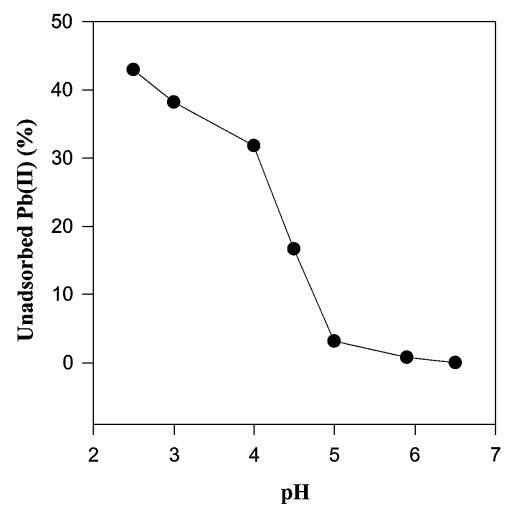

Fig. 3 Influence of the $\mathrm{pH}$ on the adsorption of $\mathrm{Pb}(\mathrm{II})$ on modified activated carbon. Conditions: initial lead(II) values, $50 \mathrm{ml}$ of 1.0 $\mu \mathrm{g} / \mathrm{ml}$; washing solution, $10 \mathrm{ml}$ of $0.5 \mathrm{M} \mathrm{HNO}_{3}$.

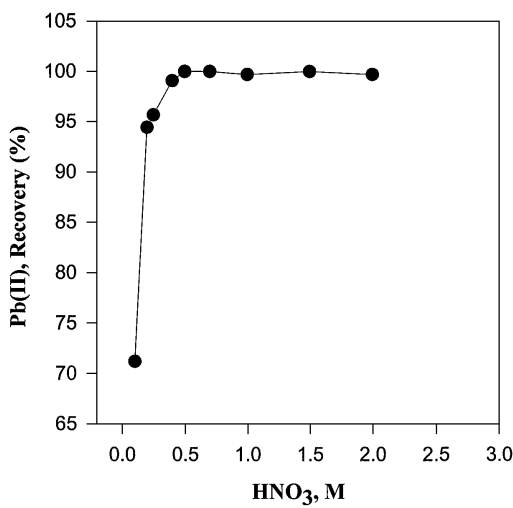

Fig. 4 Influence of the $\mathrm{HNO}_{3}$ concentration on the washing step.

PGR.

The stability of the adsorbed PGR on activated carbon was checked by the elution of a column (containing the modified activated carbon) with $10 \mathrm{ml}$ of $2.0 \mathrm{M} \mathrm{HNO}_{3}$. The results showed that the ligand did not wash by $2.0 \mathrm{M}$ nitric acid, and was stable on the surface of active carbon. The experiment was repeated by washing the column with $5 \mathrm{~L}$ of a $0.2 \mathrm{M} \mathrm{HNO}_{3}$ solution. The results showed that the ligand (PGR) did not wash during long-time elution by the mobile phase.

The influence of the $\mathrm{pH}$ of the sample solution in the preconcentration step of $\mathrm{Pb}$ (II) was also studied. For this purpose, $50 \mathrm{ml}$ of $1.0 \mu \mathrm{g} / \mathrm{ml} \mathrm{Pb}$ (II) at different $\mathrm{pH}$ values was passed through a modified solid phase. The eluent solution was then checked for the $\mathrm{Pb}$ (II) concentration by FAAS (Fig. 3). The results show that the optimum $\mathrm{pH}$ for the adsorption of $\mathrm{Pb}$ (II) on the modified activated carbon was 6.0. This is due to the fact that in an acidic solution, the formation constant of the $\mathrm{Pb}$ (II)-PGR complex decreases due to the protonation of PGR, whereas at higher $\mathrm{pH}$ values $(\mathrm{pH}>6), \mathrm{Pb}(\mathrm{II})$ reacts with hydroxyl ions to produce $\mathrm{Pb}(\mathrm{OH})_{2}$. Therefore, phthalate buffer with $\mathrm{pH} 6.0(0.01 \mathrm{M})$ was used for the preconcentration step.

Different concentrations of $\mathrm{HNO}_{3}(10 \mathrm{ml})$ in the interval range of $0.10-2.0 \mathrm{M}$ were used to investigate the efficiency and ensure the quantitative elution of the preconcentrated lead(II) ions from the column (Fig. 4). The results showed that $0.50 \mathrm{M}$ $\mathrm{HNO}_{3}$ is suitable to remove $100 \%$ of $\mathrm{Pb}$ (II) from the solid sorbent. In order to optimize the volume of $0.50 \mathrm{M} \mathrm{HNO}_{3}, 50$ $\mathrm{ml}$ of $0.10 \mu \mathrm{g} / \mathrm{ml} \mathrm{Pb}$ (II) was passed through modified active
Table 2 Determination of $\mathrm{Pb}(\mathrm{II})$ in water samples

\begin{tabular}{|c|c|c|c|}
\hline Sample & $\begin{array}{l}\mathrm{Pb} \text { (II) added/ } \\
\quad \mathrm{ng} \mathrm{ml}^{-1}\end{array}$ & $\begin{array}{l}\mathrm{Pb}(\mathrm{II}) \text { found }(n=4) / \\
\mathrm{ng} \mathrm{ml}^{-1}\end{array}$ & Recovery, \% \\
\hline \multicolumn{4}{|l|}{ Zayandeh Roud } \\
\hline \multirow{4}{*}{ River water (I) } & - & 0.0 & 1 \\
\hline & 10 & $9.8 \pm 0.4$ & 98 \\
\hline & 20 & $20.8 \pm 0.6$ & 104 \\
\hline & 30 & $30.5 \pm 0.6$ & 102 \\
\hline \multirow[t]{4}{*}{ Waste water (I) } & - & $15.8 \pm 0.5$ & - \\
\hline & 10 & $26.2 \pm 0.6$ & 102 \\
\hline & 20 & $35.0 \pm 0.7$ & 98 \\
\hline & 30 & $44.8 \pm 0.7$ & 98 \\
\hline \multirow{4}{*}{ Waste water (II) } & - & $27.9 \pm 0.6$ & - \\
\hline & 10 & $37.5 \pm 0.7$ & 99 \\
\hline & 20 & $48.7 \pm 0.7$ & 102 \\
\hline & 30 & $56.4 \pm 0.8$ & 97 \\
\hline
\end{tabular}

carbon under the optimum conditions. Then, the solid phase was washed with different volumes of $0.5 \mathrm{M} \mathrm{HNO}_{3}$ (3.0 - 10 $\mathrm{ml})$. The results showed that $5.0 \mathrm{ml}$ of $0.50 \mathrm{M} \mathrm{HNO}_{3}$ is suitable to remove $100 \%$ of $\mathrm{Pb}$ (II) from the solid phase.

The influence of the sample flow rate for the elution of lead(II) from the column was also investigated. For this purpose, $50 \mathrm{ml}$ of a $0.10 \mu \mathrm{g} / \mathrm{ml} \mathrm{Pb}$ (II) solution was passed through a modified column. Then, the adsorbed lead(II) was washed with $5.0 \mathrm{ml}$ of a $0.50 \mathrm{M} \mathrm{HNO}_{3}$ solution at various flow rates. The lead(II) contents were then measured by FAAS. The results showed that increasing the flow rates of sample did not affect the recovery of $\mathrm{Pb}(\mathrm{II})$ from the modified activated carbon, and that the recovery was $100 \%$. Therefore, a flow rate of 10 $\mathrm{ml} / \mathrm{min}$ was used for a further study.

The capability of the modified carbon active with the elution cycle was studied using two separate 25 -sample solutions, each sample containing a $100 \mathrm{ml}$ solution of $0.10 \mu \mathrm{g} / \mathrm{ml} \mathrm{Pb(II)} \mathrm{under}$ the optimum conditions described above. The calculated recoveries plus the standard deviations were $(99.4 \pm 1.6) \%$ and $(99.5 \pm 1.7) \%$, respectively. This behavior also showed a strong adsorption of PGR on activated carbon.

Our experiments showed that the capacity of the solid adsorbent is equal to $0.080 \mathrm{mg}$ of lead per one gram of modified activated carbon.

The influence of matrix ions in water samples on the recovery of lead(II) ions was also investigated. No interference was observed from large amounts (10000-fold) of alkaline, alkaline earth metal ions, $\mathrm{Fe}^{3+}, \mathrm{Mn}^{2+}, \mathrm{Cu}^{2+}, \mathrm{Fe}^{2+}, \mathrm{Zn}^{2+}, \mathrm{Cd}^{2+}, \mathrm{Cr}^{3+}, \mathrm{Bi}^{3+}$ $\mathrm{Co}^{2+}$, and $\mathrm{Ni}^{2+}$. These ions could not be adsorbed on the column because of the low tendency of PGR to make complexes with these metal ions at that $\mathrm{pH}$.

The method was used for three different water samples for lead(II) determination. The river-water samples were used directly to measure the lead(II) contents by the proposed method after being filtered with filter paper (Whatman No. 1). For each sample, $2000 \mathrm{ml}$ was passed through the column, as explained by the recommended procedure. Then, the lead(II) contents in the washed solution were determined by FAAS. The results are given in Table 2 .

The new developed method is selective and repeatable for the preconcentration and determination of ultra-trace amounts of lead(II). The modified active carbon phase is stable for several treatments of the sample solution, without the need to use any chemical reagents. The method can be used for the preconcentration of lead(II) down to $0.001 \mu \mathrm{g} / \mathrm{ml}$. The recovery of spliced lead(II) was in the range of $98-103 \%$. 


\section{Acknowledgements}

The authors express their gratitude to Center of Excellency in Chemistry of Isfahan University of Technology for the support of this work.

\section{References}

1. I. Rodunshkin and T. Ruth, J. Anal. At. Spectrom., 1997, 12, 1181 .

2. I. Narin and M. Soylak, Fresenius Environ. Bull., 1999, 8, 24.

3. T. Aydemir and S. Gucer, Chem. Anal. [Warsaw], 1996, 41,829 .

4. M. B. O. Gvacomelli, J. B. B. Da Silva, and A. J. Curtius, Talanta, 1998, 47, 877.

5. M. Soylak, Y. Akkaya, and L. Elci, Fresenius Environ. Bull., 1999, 8, 453.

6. M. Yaman and S. Gucer, Ann. Chim. Rome, 1998, 88, 555.

7. Y. P. de Pena, M. Gallegos, and M. Varcareel, J. Anal. At. Spectrom., 1994, 9, 691.

8. T. Aydemir and S. Gucer, Anal. Lett., 1996, 29, 351.
9. M. Soylak, Y. Akkaya, and L. Elci, Fresenius Environ. Bull., 1999, 8, 435.

10. M. Soylak, I. Narin, and M. Dogan, Anal. Lett., 1997, 30, 2801.

11. M. Soylak, I. Narin, L. Elci, and M. Dogan, Trace Elem. Electrolytes, 1999, 16, 231.

12. I. Narin and M. Soylak, Fresenius Environ. Bull., 1999, 8, 24.

13. M. Soylak and M. Dogan, Anal. Lett., 1996, 29, 635.

14. J. B. B. da Silva, M. B. O. Giacomelli, and A. J. Curtius, Analyst, 1999, 124, 1249.

15. S. P. Quinaia, J. B. B. da Silva, M. C. E. Rollemberg, and A. J. Curtius, Talanta, 2001, 54, 687.

16. I. Narin. M. Soylak, L. Elci, and M. Dogan, Talanta, 2000, 52,1041 .

17. C. C. Huang and M. H. Yang, Anal. Chem., 1997, 69, 3930.

18. A. A. Ensafi, B. Rezaei, and M. Beglari, Anal. Lett., 2002, 35, 909 .

19. A. A. Ensafi and M. Arab Chamjangali, Spectrochim. Acta, Part A, 2002, 58, 2835.

20. A. A. Ensafi and M. Keyvanfard, Spectrochim. Acta, Part A, 2002, 58, 1567.

21. A. A. Ensafi and B. Rezaei, Anal. Lett., 1993, 26, 1771. 